

P-ISSN: 2349-8528

E-ISSN: 2321-4902

www.chemijournal.com

IJCS 2020; 8(3): 2776-2780

(C) 2020 IJCS

Received: $20-03-2020$

Accepted: 24-04-2020

Nisha

Ph.D. Scholar, Department of

Agricultural Economics,

CCSHAU, Hisar, Haryana, India

DP Malik

Professor and Head, Department of Agricultural Economics,

CCSHAU, Hisar, Haryana, India

\section{KK Kundu}

Associate Professor, Department of Agricultural Economics,

CCSHAU, Hisar, Haryana, India

\section{Neeraj}

Assistant Scientist, Department

of Agricultural Economics,

CCSHAU, Hisar, Haryana, India

Corresponding Author:

Nisha

Ph.D. Scholar, Department of

Agricultural Economics,

CCSHAU, Hisar, Haryana, India

\section{Economic returns and elements influencing sugarcane cultivation in Haryana}

\author{
Nisha, DP Malik, KK Kundu and Neeraj
}

DOI: https://doi.org/10.22271/chemi.2020.v8.i3an.9633

\begin{abstract}
The present investgation was carried out to work out costs and returns and to identify the various elements influencing sugarcane acreage in Haryana. One block having maximum area under sugarcane namely Radaur and Rohtak from Yamunanagar and Rohtak were selected respectively. 20 farmers each from three villages of each selected block were interviewed to extract desired information. In Yamunanagar, per hectare cost of cultivation, yield, gross returns and net returns attained from the planted \& ratoon sugarcane were Rs. 244517, 986 quintals, Rs. 337120 and Rs. 92604 \& Rs. 187217, 950 quintals, Rs. 322730 and Rs. 135513 respectively. In Rohtak, the corresponding figures for planted \& ratoon sugarcane were Rs. 210832, 798 quintals, Rs. 274554 and Rs. 63727 \& Rs. 146995, 702 quintals, Rs. 241410 and Rs. 94415, respectively. Requirement of number of irrigations, labour scarcity, unavailability of machines for harvesting, payment in installments were perceived as the major constraints.
\end{abstract}

Keywords: Gross returns, B-C ratio, constraints, ratoon and planted sugarcane

\section{Introduction}

In India, sugarcane is the most important commercial crop which is grown over 2.57 per cent of its gross cropped area (Upreti \& Singh, 2017). India has 5.11 million ha of area under sugarcane cultivation in the world and it is the second largest producer of sugarcane after Brazil in the world with cane production of 400.16 million tonnes in 2018-19. Sugarcane plays a crucial role in the agro-industrial economy of India. A large number of agricultural labourers and about 60 million sugarcane growers are engaged in the cultivation of sugarcane and ancillary activities which backed to 7.5 per cent of the rural population (Indian Sugar Mills Association, 2017).

A dramatic increase of 93 per cent was registered in sugarcane production in India during the decade 1951-61 as a consequence of diversification of agriculture but this came down to 14.90 per cent growth between 1960-61 and 1970-71 mainly due to the internal market fluctuations leading to farmers' withdrawal of land under sugarcane. However, during the decade 1971-81 production began increasing again with the initiation of establishing sugar mills with a growth rate of 22 per cent. An all-time record of 299.30 million tonnes sugarcane production was attained in 1999-2000 and after that varying trend has been witnessed. Similar to the production, area under sugarcane cultivation registered a rapid growth from 1.70 million ha in 1950-51 to 4.10 million ha in 1998-99 and after that it increased at a slower rate. Cost of cultivation of sugarcane in India has witnessed increasing trend due to escalation of prices of inputs used, higher wages of labour and increased hiring charging of machines. However, growth of value of output has outpaced the growth of cost of cultivation and thus rising trend of profitability was observed (Upreti \& Singh, 2017). The production of sugarcane has touched upto 400.16 million tonnes in 2015-16 with cane yield of 782 quintals ha ${ }^{-1}$ (John and Mali, 2016) ${ }^{[2]}$. However, there are some problems like extreme drought condition, lack of finance and credit facilities, delay in transportation of cane, payments not done in time, nonremunerative price of the produce, trouble by harvesting gang, poor road conditions, nonavailability of ready use FYM and inadequate irrigation facilities were amongst the major constraints faced by the growers in Parbhani district of Maharashtra (Chand et al., 2016). The most important constraint responsible for yield gaps in sugarcane cultivation is shortage of labour during crucial farm operations. 
It necessitates the urgency of mechanization in sugarcane if constraints are addressed and a proper package of practices is being followed by growers (Singh et al, 2018) ${ }^{[18]}$.

Haryana is one of the sugarcane producing states in north India. Farmers were well oriented with recent production technologies of sugarcane cultivation and made efforts to achieve highest productivity per unit of land by employing quality seed and improved agronomic practices with available resources. Keeping in view an attempt has been made in to ascertain the problems faced by the growers in cultivation of sugarcane in Haryana.

\section{Materials and Methods}

The present study was conducted in Yamunanagar and Rohtak districts of Haryana state. About 120 farmers from 6 villages (three villages from each block of identified district) were selected randomly. A detailed information was collected about inputs use pattern and the prices of inputs to work out the cost of cultivation. The yield and returns from planted \& ratoon sugarcane and various restraints influencing sugarcane acreage was ascertained from the selected respondent-farmers pertaining to availability of irrigation water, availability and prices of seed setts, use of chemical fertilizers and their prices, various agronomic practices adopted, plant protection chemicals, transportation of produce, disposal pattern of produce, payment of produce, price announced by state government etc. were recorded through interaction with identified farmers. The opinion of sugarcane cultivators about various factors like size of operational holding, incentives for inputs used in sugarcane cultivation, availability of labour for various farm operations etc. influencing area allocation for sugarcane at individual farm level were also mined through interviewing cultivators.

\section{Results and Discussion}

1. Costs and returns of sugarcane cultivation in Haryana: The per hectare total cost of cultivation of planted and ratoon sugarcane in Rohtak was worked out to be Rs. 210832 and Rs. 146995, respectively. The total variable cost consists of expenses incurred on various inputs such as preparatory tillage, setts \& setts treatment, planting, inter-cultural operations, fertilizers, irrigation, plant protection chemicals, harvesting, interest on variable expenses and other miscellaneous charges. The total fixed cost comprises of transportation charges, rental value of land, management charges (10\% of total expenses) and risk charges (10\% of total expenses). The incidence of insect-pests was higher in ratoon condition owing to higher quantity of plant protection chemicals consumption. The per hectare yield and monetary value of main produce, yield and monetary value of byproduct, gross returns and net returns attained from the planted sugarcane were worked out to be 798 quintals, Rs. 263454, 159 quintals, Rs. 11101, Rs. 274554 and Rs. 63727, respectively. The corresponding values for ratoon sugarcane were worked out to be 702 quintals, Rs. 231556, 141 quintals, Rs. 9854, Rs. 241410 and Rs. 94415 respectively. The returns over variable cost were found higher in ratoon sugarcane (Rs. 176599) as compared to the planted sugarcane (Rs. 158650) as there farm operation like preparatory tillage and sowing of setts as well as excluding the cost of setts and setts treatment. The B-C ratio was worked out to be 1.30 and 1.64 , respectively in planted and ratoon conditions. The higher value of B-C ratio in ratoon sugarcane was owing to less cost incurred in cultivation of ratoon crop.

Table 1: Costs and returns of planted and ratoon sugarcane in Haryana

\begin{tabular}{|c|c|c|c|c|c|c|c|c|c|}
\hline \multirow{3}{*}{$\begin{array}{l}\text { Sr. } \\
\text { No. }\end{array}$} & \multirow{3}{*}{ Particulars } & \multicolumn{4}{|c|}{ Rohtak } & \multicolumn{4}{|c|}{ Yamunanagar } \\
\hline & & \multicolumn{2}{|c|}{ Planted } & \multicolumn{2}{|c|}{ Ratoon } & \multicolumn{2}{|c|}{ Planted } & \multicolumn{2}{|c|}{ Ratoon } \\
\hline & & Qty & Value & Qty & Value & Qty & Value & Qty & Value \\
\hline 1 & Total Variable Cost (TVC) & & $\begin{array}{l}115909 \\
(54.97)\end{array}$ & & $\begin{array}{c}64811 \\
(44.09)\end{array}$ & & $\begin{array}{l}120975 \\
(49.48)\end{array}$ & & $\begin{array}{c}73657 \\
(39.34)\end{array}$ \\
\hline 2 & Rental value of land & & $\begin{array}{c}61750 \\
(29.28)\end{array}$ & & $\begin{array}{c}61750 \\
(42.01)\end{array}$ & & $\begin{array}{c}85927 \\
(34.88)\end{array}$ & & $\begin{array}{l}85927 \\
(45.89)\end{array}$ \\
\hline 3 & Total Fixed Cost (TFC) & & $\begin{array}{c}94924 \\
(45.02) \\
\end{array}$ & & $\begin{array}{c}82184 \\
(55.91) \\
\end{array}$ & & $\begin{array}{l}123542 \\
(50.52) \\
\end{array}$ & & $\begin{array}{l}113561 \\
(60.66) \\
\end{array}$ \\
\hline 4 & $\begin{array}{c}\text { Total Cost } \\
(\mathrm{TVC}+\mathrm{TFC}) \\
\end{array}$ & & $\begin{array}{c}210832 \\
(100.00) \\
\end{array}$ & & $\begin{array}{c}146995 \\
(100.00) \\
\end{array}$ & & $\begin{array}{c}244517 \\
(100.00) \\
\end{array}$ & & $\begin{array}{c}187217 \\
(100.00) \\
\end{array}$ \\
\hline 5 & Gross Returns & & $\begin{array}{c}274554 \\
(100.00) \\
\end{array}$ & & $\begin{array}{c}241410 \\
(100.00) \\
\end{array}$ & & $\begin{array}{c}337120 \\
(100.00) \\
\end{array}$ & & $\begin{array}{c}322730 \\
(100.00) \\
\end{array}$ \\
\hline a. & Main Product (Qtls) & 798.00 & $\begin{array}{l}263454 \\
(95.96)\end{array}$ & 702.00 & $\begin{array}{l}231556 \\
(95.91)\end{array}$ & 986.00 & $\begin{array}{l}325474 \\
(96.55)\end{array}$ & 950.00 & $\begin{array}{l}313406 \\
(97.11)\end{array}$ \\
\hline b. & By-Product (Qtls) & 159.00 & $\begin{array}{l}11101 \\
(4.04)\end{array}$ & 141.00 & $\begin{array}{c}9854 \\
(4.09) \\
\end{array}$ & 166.00 & $\begin{array}{l}11647 \\
(3.45) \\
\end{array}$ & 133.00 & $\begin{array}{l}9324 \\
(2.89) \\
\end{array}$ \\
\hline 6 & Net Returns & & 63727 & & 94415 & & 92604 & & 135513 \\
\hline 7 & Returns over variable cost & & 158650 & & 176599 & & 216415 & & 249074 \\
\hline 8 & $\mathrm{~B}-\mathrm{C}$ ratio & & 1.30 & & 1.64 & & 1.38 & & 1.72 \\
\hline 9 & B-C ratio over Variable cost & & 2.37 & & 3.72 & & 2.79 & & 4.38 \\
\hline
\end{tabular}

Note: Figures in parenthesis indicate the percentage to total

The per hectare total cost of cultivation was worked out to be Rs. 244517 and Rs. 187217, in planted and ratoon conditions, respectively, of sugarcane in Yamunanagar. The per hectare yield and monetary value of main produce, yield and monetary value of by-product, gross returns and net returns attained from the planted sugarcane was worked out to be 986 quintals, Rs. 325474, 166 quintals, Rs. 11647, Rs. 337120 and Rs. 92604, respectively. The corresponding values for ratoon sugarcane were worked out to be 950 quintals, Rs. 313406,
133 quintals, Rs. 9324, Rs. 322730 and Rs. 135513 respectively. The returns over variable cost were found higher in ratoon sugarcane (Rs. 249074) as compared to the planted sugarcane (Rs. 216145) as a result of exclusion of field preparation and planting operations as well as no use of setts/seed and seed treatment. The B-C ratio was worked out to be 1.38 and 1.72 , respectively in planted and ratoon conditions. The higher value of $\mathrm{B}-\mathrm{C}$ ratio in ratoon sugarcane was achieved due to less expense involved in cultivation of 


\section{ratoon crop.}

There were several reasons like level of use of inputs, wages of labour, seed rate, rental value of land, transportation cost caused difference in level of output, cost incurred and net returns on sampled farms in identified districts. The value of B-C ratio in both districts was higher for ratoon sugarcane as compared to planted sugarcane as no expenses incurred owing to exclusion of preparatory tillage and sowing of setts operations as well as planting materials and treatment of setts. Sarvanan (2016) ${ }^{[11]}$ in their study on costs and returns of sugarcane production in Erode district of Tamil Nadu reported similar results depicting 14.40 per cent of total cost incurred on seed, 6.04 per cent on fertilizer investment and 3.61 per cent on plant protection chemicals. Kant et al. (2015) ${ }^{[3]}$ in their study on cost of cultivation of sugarcane in Meerut district of Uttar Pradesh reported that the cost of cultivation is more in case of planted sugarcane i.e. Rs. 172679 as compared to the ratoon sugarcane i.e. Rs. 129753. Kumar et al. (2014) ${ }^{[5]}$ in their study on sugarcane production in Meerut district of Uttar Pradesh also reported that the major share of total cost in planted as well as the ratoon crop was incurred on the rental value of land $(39.66 \%)$ similar to the results attained in the present study. Nagpure et al. (2004) ${ }^{[8]}$ in their study conducted in Vidarbha region of Maharashtra also exhibited that net income on per hectare basis and efficiency of per rupee investment was found to be higher in case of ratoon crop as against suru main crop. Further, similar results like higher net returns and less average cost were observed in ratoon sugarcane as compared to planted sugarcane (Kishore, 2001).

\section{Elements influencing sugarcane acreage}

The opinion of 120 sugarcane growers were gathered regarding various constraints in cultivation of sugarcane, its harvesting and disposal of cane in the study area. Besides, information pertaining to various factors influencing the decision of individual farmer in allocation of area for sugarcane was extracted from growers using personal contact approach.

\subsection{Constraints faced in the cultivation of sugarcane}

All the farmers were unanimous in their views about the problem of non-availability of machine for harvesting (Table 2). Majority of farmers (more than $75 \%$ ) in both districts were of view that the cultivation of second crop after sugarcane in a year is not possible as its duration is about 8-10 months and staggered disposal of cane in sugar mills. Shortage of labour for harvesting of sugarcane was the other important problem faced by about 71.67 per cent and 46.67 per cent of respondents of Yamunanagar and Rohtak, respectively. The harvesting of sugarcane was mainly done manually and all growers were dependent on the migratory labour particularly from eastern India (Eastern Uttar Pradesh and Bihar). The harvesting charges were also higher as payment for harvesting of per quintal was in the range of Rs. 40-50 in the harvesting season. The harvesting period of sugarcane continued for 6-7 months (October to May). About 48 respondents (80\%) of Yamunanagar and 39 respondents $(65 \%)$ of Rohtak expressed their opinion that sugarcane crop required higher amount of irrigation water (number of irrigations) as compared to the other crops causing decline in the area under sugarcane.

Table 2: Constraints faced in cultivation of sugarcane

\begin{tabular}{|c|c|c|c|c|c|}
\hline \multirow{3}{*}{\begin{tabular}{|l} 
Sr. \\
No.
\end{tabular}} & \multirow{3}{*}{ Particulars } & \multicolumn{4}{|c|}{ Study area } \\
\hline & & \multicolumn{2}{|c|}{ Yamunanagar } & \multicolumn{2}{|c|}{ Rohtak } \\
\hline & & Frequency & Percent & Frequency & Percent \\
\hline 1 & Non-availability of machine for harvesting & 60 & 100.00 & 60 & 100.00 \\
\hline 2 & Impossibility for the cultivation of second crop after sugarcane in a year & 46 & 76.67 & 45 & 75.00 \\
\hline 3 & Scarcity of labour within the village & 44 & 73.33 & 39 & 65.00 \\
\hline 4 & Shortage of labour during harvesting period & 43 & 71.67 & 28 & 46.67 \\
\hline 5 & Higher number of irrigation required & 48 & 80.00 & 39 & 65.00 \\
\hline 6 & Requirement of higher quantity of seed/setts & 09 & 15.00 & 09 & 15.00 \\
\hline 7 & Non-availability of seed/ setts for improved varieties & 09 & 15.00 & 07 & 11.67 \\
\hline 8 & No use of micro-nutrients & 10 & 16.67 & 03 & 5.00 \\
\hline 9 & Poor quality of irrigation water available & 07 & 11.67 & 06 & 10 \\
\hline 10 & Higher quantity of chemical fertilizers & 49 & 81.67 & 50 & 83.33 \\
\hline 11 & Scarcity of labour for manual hoeing/inter-culture operations & 33 & 55.00 & 08 & 13.33 \\
\hline 12 & Non-availability of recommended plant protection chemicals in the market & 19 & 31.67 & 21 & 35.00 \\
\hline 13 & Non-awareness about biological control of insect-pests & 24 & 40.00 & 12 & 20.00 \\
\hline 14 & Higher prices of plant protection chemicals & 16 & 26.67 & 17 & 28.33 \\
\hline 15 & Delayed planting of sugarcane & 12 & 20.00 & 13 & 21.67 \\
\hline 16 & Non-availability of implements for control of weeds & 09 & 15.00 & 10 & 16.67 \\
\hline 17 & Lack of knowledge about recommended pesticides for control of insect-pests and diseases & 08 & 13.33 & 09 & 15.00 \\
\hline 18 & Non-availability of effective weedicides/herbicides in market & 07 & 11.67 & 09 & 15.00 \\
\hline
\end{tabular}

The other constraints such as delayed planting of crop, requirement of higher quantity of seed, non-availability of seed for improved varieties, inadequate use of micro nutrients, poor quality of irrigation water and higher requirement of chemical fertilizers were of negligible importance. The results revealed that among the remaining constraints, the major one faced by the farmers of Yamunanagar was the scarcity of labour for manual hoeing/ inter-culture operations, whereas, it was the non-availability of recommended plant protection chemicals in the market, was observed in Rohtak district. The constraint which was found to be somewhat similar in both the districts was that the farmers are not aware about the biological control of insect-pests. About one fourth farmers of both districts expressed that the prices of plant protection chemicals (pesticides) were on higher side. Other constraints such as non-availability of mechanical device for control of weeds, lack of knowledge about the recommended pesticides for effective control of biotic stresses and non-availability of effective weedicides /herbicides in the market were of negligible importance. 
2.2 Constraints faced in the disposal of sugarcane

About 35.00 and 61.67 per cent farmers of Yamunanagar and
Rohtak, respectively, expressed that the payment of sugarcane produce was made in installments by sugar mills (Table 3 ).

Table 3: Constraints faced in the disposal of sugarcane in Haryana

\begin{tabular}{|c|c|c|c|c|c|}
\hline S. & \multirow{2}{*}{ Particulars } & \multicolumn{2}{c|}{ Yamunanagar } & \multicolumn{2}{c|}{ Rohtak } \\
\cline { 2 - 6 } No. & Frequency & Percent & Frequency & Percent \\
\hline 1 & Payment is made in installments by sugar mill & 21 & 35.00 & 37 & 61.67 \\
\hline 2 & Payment of arrear of previous year & 11 & 18.33 & 23 & 38.33 \\
\hline 3 & Sugarcane price announced by state government & 12 & 20.00 & 08 & 13.33 \\
\hline 4 & Purchase of sugarcane at higher price by agency other than sugar mill & 06 & 10.00 & 14 & 23.33 \\
\hline 5 & Mode of payment through transfer in bank account & 60 & 100.00 & 60 & 100.00 \\
\hline
\end{tabular}

It was found that the $11(18.33 \%)$ and $23(38.33 \%)$ respondents said that payment of cane disposed off in previous year was still pending. The other constraints such as the price announced by the state government and purchasing of sugarcane by other agencies providing higher prices were not of much importance. However, it was noticed that the payment of sugarcane was credited in bank account of growers. Majority of sugarcane growers were of the opinion that disposal of sugarcane in mill is time consuming process in peak harvesting season indicating inefficient disposal procedure.

\subsection{Factors influencing sugarcane acreage}

It depicts that all the respondents of Yamunanagar as well as Rohtak were of common opinion that the small size of operational land holding and returns from sugarcane once in a year influenced area under the sugarcane cultivation (Table 4). The small size of operational land holding may be attributed to the declining land availability per household and fragmentation of land holding. About 52 (86.67\%) and 45 $(75 \%)$ respondents of Yamunanagar and Rohtak shared that the lack of incentives for purchase of inputs like seeds, machines, plant protection chemicals also affect the sugarcane acreage in the study area. Non-availability of machines for sowing, inter-cultural operations and harvesting was the other constraints faced by $51(85 \%)$ and $60(100 \%)$ respondents of Yamunanagar and Rohtak, respectively. The other factors affect the area under sugarcane were non-availability of labour from within the village,

Table 4: Various factors influencing sugarcane acreage in Haryana

\begin{tabular}{|c|c|c|c|c|c|}
\hline \multirow{2}{*}{\begin{tabular}{|l|} 
Sr. \\
No.
\end{tabular}} & \multirow{2}{*}{ Particulars } & \multicolumn{2}{|c|}{ Yamunanagar } & \multicolumn{2}{|c|}{ Rohtak } \\
\hline & & Frequency & Percent & Frequency & Percent \\
\hline 1 & Small size of operational land holding & 60 & 100.00 & 60 & 100.00 \\
\hline 2 & Returns once in year & 60 & 100.00 & 60 & 100.00 \\
\hline 3 & Non-availability of machines for sowing, inter-cultural operations, harvesting & 51 & 85.00 & 60 & 100.00 \\
\hline 4 & Lack of incentives for purchase of inputs like seed, machines, plant protection chemicals & 52 & 86.67 & 45 & 75.00 \\
\hline 5 & Non-availability of labour within the village & 44 & 73.33 & 39 & 65.00 \\
\hline 6 & Higher requirement of labour for various farm operations like (sowing, tying, harvesting) & 33 & 55.00 & 44 & 73.33 \\
\hline 7 & Higher income from competing crops grown in rabi and kharif seasons & 49 & 81.67 & 14 & 23.33 \\
\hline 8 & More time consumption in disposal of cane in sugar mill & 31 & 51.67 & 26 & 43.33 \\
\hline 9 & Payment made in installment & 21 & 35.00 & 37 & 61.67 \\
\hline 10 & Non-availability of machines for spraying of plant protection chemicals & 13 & 21.67 & 22 & 36.67 \\
\hline 11 & Delay in payment by sugar mill & 11 & 18.33 & 23 & 38.33 \\
\hline 12 & Insufficient crushing period of sugar mill & 50 & 83.33 & 38 & 63.33 \\
\hline 13 & Inadequate crushing capacity of sugar mill for demarcated area & 11 & 18.33 & 13 & 21.67 \\
\hline 14 & Yield penalty on the productivity of sugarcane by intercropping practices & 3 & 5.00 & 16 & 26.67 \\
\hline 15 & Non-availability of improved varieties & 9 & 15.00 & 7 & 11.67 \\
\hline 16 & Area allocation as per price announced by State Government & 33 & 55.00 & 38 & 63.33 \\
\hline 17 & Source and availability of irrigation water & 51 & 85.00 & 60 & 100.00 \\
\hline 18 & Government export-import policy & 9 & 15.00 & 8 & 13.33 \\
\hline
\end{tabular}

higher requirement of labour for various farm operations particularly for sowing, tying, harvesting etc. The higher income from competing crops like wheat and rice grown in rabi and kharif seasons in the study area also influenced the allocation of area for sugarcane cultivation. In Yamunanagar, about $31(51.67 \%)$ respondents informed that more time was consumed in disposal of cane in sugar mill. Whereas, in Rohtak, 37 (61.67\%) respondents expressed that the payment was made in installments. The features which had negligible effect on the area allocation under sugarcane were nonavailability of machines for spraying of plant protection chemicals, delay in payment by sugar mill, insufficient crushing period of sugar mills, inadequate crushing capacity of existing sugar mills to crush cane of demarcated area, yield penalty on the productivity of sugarcane by inter-cropping practices, non-availability of improved varieties and government export-import policies. It was also revealed that $33(55 \%)$ and $38(63.33 \%)$ respondents of Yamunanagar and Rohtak voiced that the area allocation under sugarcane was also largely inclined by State Advised Price (SAP) announced by state government. More than third-fourth of respondents in both districts articulated that source and availability of irrigation water was important constituent for cultivation of sugarcane in the study area.

Among the situational constraints as stated above, the problems like non-availability of irrigation water at proper time, non-availability of labour for inter-cultural operations, high cost of agro-chemicals, inadequate transportation facilities were faced by more than 80 per cent of farmers (150) in cultivation of sugarcane in Maharashtra (Lahoti et al., 2010) ${ }^{[6]}$. Further, it was also revealed that more than half of sampled farmers reported that payment through 
installments was also bottleneck in sugarcane cultivation. The labour shortage for various operations in sugarcane cultivation was also visualized in various studies (Mande and Thombre, 2009; Rao, 2012) ${ }^{[7,9]}$.

The problems like availability of chemical fertilizers, small size of land holding, non-availability of ready use FYM, inadequate irrigation facilities, long dry spell, inadequate finance and credit facilities, delay in transportation of cane, delayed payments, trouble by harvesting gang, poor road conditions were reported in sugarcane cultivation in various regions of Maharashtra (Jawanjal et al., 2015; Riteish et al., 2016) ${ }^{[1,10]}$.

\section{Conclusions}

The per hectare cost of cultivation and gross returns were higher in planted conditions as compared to the ratoon conditions in both districts of Haryana. The value of B-C ratio and $\mathrm{B}-\mathrm{C}$ ratio over variable cost of sugarcane was found higher in ratoon condition as compared to the planted conditions in the study area as exclusion of certain farm operations and seed. The requirement of higher number irrigations because of long time standing crop in the field and single crop cultivation in a year, higher harvesting cost involvement due to absence of cost effective harvesting machines were the opinions of majority of sampled farmers. Scarcity of labour for manual hoeing/ inter-cultural operations trailed by lack of knowledge about the biological control of insect-pests was the major constraints faced by the farmers. The most of farm operations in cultivation of sugarcane like planting, hoeing/weeding, harvesting, and loading of cane were largely dependent on availability of migratory labour from eastern part of India. Payment by sugar mills in number of installments, pending payment of previous year, declining size of operational holdings, returns once in year and higher income from competing cropping systems were other plausible reasons compelling the sugarcane acreage in the state.

\section{References}

1. Jawanjal BG, Naik VG, Talathi JM, Malave DB, Wagale SA. Cost, returns and profitability in sugarcane cultivation in Konkan region. International Journal of Commerce and Business Management. 2015; 8(1):17-22.

2. John JM, Sujata S. An economic analysis of area, production, yield and export of sugarcane in India. Acme Intellects International Journal of Research in Management, 2016, 16. www.acmeintellects.org

3. Kant K, Tripathi SP, Meena M. Cost of cultivation of sugarcane crop in Meerut district of Uttar Pradesh. International Journal of Forestry and Crop Improvement. 2015; 6(1):41-48.

4. Kishor R. A Study of economic analysis of sugarcane production in central plains agro-climatic zone of UP. Cooperative Sugar. 2001; 32(9):715-733.

5. Kumar T, Singh HL, Jawla SK, Sachan S. Cost and Returns of Sugarcane Production at different size groups of farms in district Meerut, India. Annals of Agri-Bio Research. 2014; 19(3):561-565.

6. Lahoti SR, Chole RR, Rathi NR. Constraints in adoption of sugarcane production technology. Agricultural Science Digest. 2010; 30(4):270-272.

7. Mande JV, Thombre BM. Adoption of cultivation practices by sugarcane growers. Agricultural science digest. 2009; 29(3):178-181.
8. Nagpure SC, Jhakare AB, Khandare AP, Patil RK. Economics of sugarcane production in Vidarbha Region of Maharashtra State. Rural India. 2004; 67(6-7):123125.

9. Rao IVY. Efficiency, yield gap and constraints analysis in irrigated vis-à-vis rainfed sugarcane in north coastal zone of Andhra Pradesh. Agricultural Economics Research Review. 2012; 25(1):167-171.

10. Ritesh AC, Pawar BR, Krishna M. Constraints faced in production and marketing of sugarcane in Parbhani district of Maharashtra. Agriculture Update. 2016; 11(3):209-213.

11. Sarvanan. An analysis of cost and returns of sugarcane production in erode district of Tamil Nadu. Indian Journal of Economics and Development, 2016, 4(8). http://ijed.informaticspublishing.com

12. Singh SP, Singh HP, Kumari M, Meena L. Assessment of Variations in Yield Gap and Constraints analysis in the Sugarcane Production in Bihar. International Journal of current microbiology and applied sciences. 2018; 7:26672675 . 